\title{
KONSELING LINTAS BUDAYA DAN AGAMA DALAM PENANGGULANGAN \\ RADIKALISME DI LINGKUNGAN SEKOLAH
}

\author{
Rena Rostini ${ }^{1}$, Siti Sri Afira Ruhyadi², Muh Miftahurrazikin ${ }^{3}$, \\ Wildan Nuril Ahmad Fauzi ${ }^{4}$ \\ 1,2,3,4,5Universitas Islam Negeri Sunan Kalijaga Yogyakarta \\ 1Email: rostinirena10@gmail.com \\ 2Email: ghaidasiti@gmail.com \\ 3Email: razikin1998@gmail.com \\ ${ }^{4}$ Email: wildannufa12@gmail.com
}

\begin{abstract}
Abstrak: Indonesia ialah negara multikultural yang memiliki budaya, agama, dan suku beragam. Hal tersebut menjadikan peluang yang besar terjadinya radikalisme di Indonesia. Paham radikalisme agama cenderung mengabaikan aspek perdamaian yang diajarkan oleh agama dan mengabaikan Bhineka Tunggal Ika. Psikologis saat remaja ialah usia yang sangat rentan juga sensitif mudah terpengaruh oleh lingkungan sekitar. Pada usia ini, remaja sedang memantapkan diri untuk mencari jati dirinya. Ada beberapa layanan yang strategis untuk menanggulangi penyebaran radikalisme di ranah Pendidikan untuk usia anak-anak dan remaja, misalnya layanan bimbingan konseling Lintas Agama dan Budaya. Layanan konseling ini dilakukan melalui konsep multibudaya yang dibutuhkan agar dapat membentuk pribadi seseorang agar dapat menghormati dalam bermacam keberagaman. Untuk itu penelitian yang dilakukan bermaksud agar dapat memperlihatkan bahwa bimbingan konseling lintas budaya dan agama yaitu bagian dari cara untuk menanamkan sikap toleransi yang tinggi sehingga tidak terjerumus dalam pemahaman yang kurang tepat terhadap keberagaman yang ada disekitarnya. Pendidikan menjadi tempat yang cocok untuk memberikan edukasi kepada siswa-siswinya untuk membentuk karakter yang memiliki jiwa dan sikap toleransi yang tinggi
\end{abstract}

Kata Kunci: Bimbingan Konseling, Lintas Agama dan Budaya, Radikalisme 


\section{PENDAHULUAN}

Dalam Kamus Besar Bahasa Indonesia (KBBI) radikalisme berasal dari kata radikal dan mempunyai arti sampai kepada yang prinsip atau secara mendasar. (Munip 2012:1151) Adapun pengertian radikalisme adalah paham yang menuntut perubahan sosial, politik menggunakan cara yang anarkis. Kelompok radikal sering dianggap sebagai kelompok mengenakan kekerasan demi mencapai tujuan kelompoknya. Radikalisme apabila dilihat dari istilah kata ini berasal dari kata "radix" atau "radicis" yang berarti akar, radikalisme diartikan sebagai "secara menyeluruh", "habis-habisan", "amat keras menuntut perubahan", dan "maju dalam berpikir dan bertindak. Sehingga radikalisme dapat diartikan seseorang yang radikalisme mempunyai pemahaman yang dalam akan sesuatu yang diyakini dan dipercaya dan memiliki keteguhan keteguhan dalam mempertahankan kepercayaannya. ${ }^{1}$

Sejak terjadinya reformasi 1998 kasus radikalisme mulai muncul di Indonesia. Masa itu terjadi banyak kerusuhan-kerusuhan yang tejadi bukan hanya terjadi di Jakarta. Semenjak saat itu sampai saat ini banyak terjadi aksi radikalisme yang terjadi antar suku maupun agama. Sebagai contoh ada di daerah Ambon terjadi pertengkaran antara agama Islam dan agama Kristen di Ambon. Selain itu ada di daerah Kalimantan Tengah lebih tepatnya di Sampit perdebatan antara suku Dayak dan Madura. Bangsa Indonesia dikenal sebagai bangsa yang berpegang teguh pada Bhineka Tunggal Ika, nilai moral, budi pekerti, tetapi situasi seolah berubah dan hilang ketika banyak terjadi kerusuhan akibat dari radikalisme. Situasi tersebut terjadi karena kekurang dari segi spiritual, adanya perbedaan tanpa didasari dengan rasa saling menghormati satu sama lain dan masalah merebutkan wilayah juga terkikisnya nilai budaya yang sudah ada sebelumnya. Permasalahan banyak terjadi bukan hanya permasalahan yang ditimbulkan oleh agama saja tetapi permasalahan agama merupakan permasalahan yang paling sering terjadi karena besarnya kontroversi antar kelompok agama menjadi rentan terhadap terjadinya permasalahan. ${ }^{2}$

Seseorang mapun kelompok yang mempunyai sikap prejudis, stereotip, dan diskriminasi merupakan penyebab timbulnya konflik karena adanya perbedaan. Prejudis adalah sikap menyamaratakan atau sikap dimana memandang semuanya secara sama atau umum, kenyataanya terdapat berbagai macam perbedaan khusus. Adapun contoh yang kongkrit misalnya ada pemikiran dari beberapa masyarakat

1 Anton Suwito. "Membangun Integritas Bangsa Di Kalangan Pemuda Untuk Menangkal Radikalisme.” CIVIS 4(2). (2014) doi: 10.26877/civis.v4i2/Juli.610. Hlm. 584.

2 Aijudin Anas. "Peran Pesantren Al Muayyad Windan Dalam Transformasi Konflik Keagamaan Di Surakarta." 2011. Hlm. 4. 
bukan muslim di barat jika orang muslim itu teroris dan anarkis. Sedangkan stereotip, adalah sikap memberi nilai atau memberikan cap kepada ciri khas kelompok. Contohnya ada menganggap bahwa suku Sunda kebanyakan materialistik, Adapun biasanya orang Padang kebanyakan yang perhitungan, orang Medan itu keras. Diskriminasi ialah prilaku yang membeda-bedakan seseorang ataupun kelompok. Biasanya hal semacam ini berhubungan erat dengan relasi antar kelompok yang mayoritas terhadap kelompok yang minoritas dalam perlakuan tidak adil. Anak-anak dan remaja ialah generasi penerus bangsa dan menjadi sasaran utama untuk dapat dipengaruhi paham-paham radikal. Maka anak-anak dan remaja perlu melakukan pengenalan konsep dasar dari keberagaman ras, suku dan agama. ${ }^{3}$

Menurut Ardi yang mana beliau mengemukakan bahwa perlunya penanganan yang tepat untuk melindungi anak-anak juga remaja agar terhindar dari radikalisme melalui Pendidikan multikultural dalam membentuk generasi yang saling menghormati dalam setiap perbedaan. ${ }^{4}$ Sedangkan menurut Ardi menjabarkan bahwa Anak-anak dan remaja adalah usia yang sedang mencari jati diri dan dibutuhkannya pengawasan agar tidak terpengaruhi akan radikalisme, cara mengawasinya misalnya melalui layanan bimbingan konseling lintas agama dan budaya agar menjadi pribadi yang mampu untuk saling menghormati dalam perbedaan agama juga suku yang ada. ${ }^{5}$

Dapat disimpulkan bahwa dalam penelitian ini guna untuk menganalis layanan bimbingan multikultural dalam mengurangi permasalahan radikalisme di lingkungan sekolah.

\section{METODE PENELITIAN}

Metode Penelitian yang digunakan yakni liblary research, dimana liblary research ialah penelitian yang dilakukan melalui cara mengumpulkan data dengan menggunakan bantuan dari berbagai material yang sudah ada di perpustakaan contohnya hasil penelitian terdahulu yang sejenis, buku referensi, catatan, artikel, juga dari berbagai jurnal yang berkesinambungan dengan masalah yang akan

${ }^{3}$ Mutia Tisa. "Prasangka Sosial Dalam Perspektif Komunikasi Antar Budaya Dan Agama." At-Tanzir: Jurnal Ilmiah Prodi Komunikasi Penyiaran Islam. 2017. Hlm. 79-80.

4 Lilam Kadarin Nuriyanto. "Bimbingan Konseling Melalui Pendidikan Multikultural terhadap Anak-Anak dan Remaja dalam Penanggulangan Paham Radikalisme." Konseling Religi: Jurnal Bimbingan Konseling Islam. 2014. 5(1): Hlm. 1.

5 Ardi Andika Wadi. "Bimbingan Konseling Lintas Agama dan Budaya dalam Penanggulangan Radikalisme bagi Remaja." Jurnal Al-Irsyad: Jurnal Bimbingan Konseling Islam 1. 2019. (2): Hlm. 172. 
diselesaikan. Liblary research ini dilakukan secara sistematis dimulai dari mengumpulkan, mengolah, lalu menyimpulkan data menggunakan teknik guna mencari jawaban atas permasalahan yang dihadapi.

Mirshad memaparkan langkah-langkah penelitian kepustakaan yaitu: (1) mencatat temuan mengenai masalah yang ada pada penelitian (2) memapadupadankan dari temuan-temuan yang ada, teori ataupun temuan baru (3) menganalisis temuan dari berbagai bacaan, yang berkaitan dengan kekurangan setiap sumber (4) memberikan gagasan yang kritis pada hasil penelitian terhadap hal yang sudah direncanakan sebelumnya dengan memberikan temuan baru dalam mengkolaborasikan pemikiran-pemikiran yang berbeda terhadap "masalah penelitian". ${ }^{6}$

\section{HASIL DAN PEMBAHASAN}

\section{Konseling Lintas Budaya dan Agama}

Langgulung mengungkapkan konseling ialah proses yang mempunyai tujuan membantu seseorang sedang berada pada fase emosi sosial yang tidak stabil. Sejalan seperti ungkapan dari Priyanto dan Anti menyebutkan konseling itu sebuah proses yang memberikan bantuan melalui interaksi verbal antara konselor dan individu yang mengalami masalah yang bertujuan untuk mengatasi permasalahan individu tersebut. ${ }^{7}$ Sedangkan Shretzer \& Stone juga membahas yakni konseling ialah suatu proses interaksi untuk memudahkan pengertian diri dan lingkungan atau klarifikasi tujuan-tujuan dan nilai-nilai yang berguna bagi tingkah laku yang akan datang. ${ }^{8}$

Pendapat dari para ahli dapat disimpulkan bahwa konseling ialah sebuah proses pemberian bantuan dari seorang yang ahli kepada individu yang memiliki permasalahan, agar individu tersebut dapat mengatasi permasalahan yang sedang dihadapinya.

Dilihat dari sisi identitas budaya, konseling lintas budaya merupakan hubungan konseling pada kebiasaan yang berbeda-beda antar konselor dengan konselinya. Menurut Rendon perbedaan budaya yang dimaksud adalah perbedaan ras atau suku. Oleh sebab itu definisi konseling lintas budaya adalah kegiatan konseling yang pesertanya dari berbagai suku atau berbagai kelompok yang berbeda atau konseling

${ }_{6}$ Milya Sari, dan Asmendri Asmendri. "Penelitian Kepustakaan (Library Research) dalam Penelitian Pendidikan IPA." Natural Science: Jurnal Penelitian Bidang IPA dan Pendidikan IPA 6(1) 2020. Hlm. 44. doi: 10.15548/nsc.v6i1.1555.

${ }^{7}$ Hartono. Psikologi Konseling. (Kencana, 2015). Hlm. 4.

8 Baidi Bukhori. "Dakwah Melalui Bimbingan dan Konseling Islam." Jurnal Konseling Religi 5(1) 2014. Hlm. 5. 
yang peserta dan konselornya memiliki perbedaan dalam hal perbedaan sosial atau suku dan budaya. ${ }^{9}$

Menurut Dedi Supriadi konseling lintas budaya ialah konseling yang di dalam nya ada interaksi antara konselor dan klien yang berasal dari latar belakang budaya yang berbeda. Hal ini dapat menyebabkan konseling tidak berjalan dengan lancar dan efektif sehingga menimpulkan prasangka negatif mengenai perbedaan tersebut. Konseling akan berjalan secara lancar, efektif jika konselor memahami juga peka terhadap budaya, menghargai perbedaan dan mempunyai keterampilan yang responsif secara kultural. Jika begitu konseling bisa dilihat sebagai berjumpanya beberapa budaya agar dapat mengenal dan menghargai perbedaan di Indonesia mengenai beberapa hal misalnya agama, suku budaya juga ras yang ada. Konseling ini juga diharapkan bisa menumbuhkan sikap menghargai perbedaan satu sama lain. ${ }^{10}$

Palme menjelaskan pendekatan yang dapat dilakukan dalam konseling lintas budaya adalah pendekatan umum, pendekatan budaya dan pendekatan transcultural atau inklusif. Pendekatan umum yang menekankan inklusif. Inklusif ialah suatu sikap yang menempatkan dirinya menjadi posisi yang sama dengan orang lain agar orang tersebut dapat berusaha memahami perspektif umum. Kemudian pendekatan budaya dimana pendekatan ini menerapkan fokus pada suatu hal yang memiliki ciri khas khusus dan kebutuhan khusus di suatu kelompok. ${ }^{11}$ Pendekatan konseling trancultural mencakup komponen berikut: (a) Konselor peka terhadapat beragamnya kebudayaan dan kecenderungan budaya berdasarkan konseling yang diterapkan. (b) Wawasan budaya konselor yang sesuai dengan budaya peserta konseling. (c) Kemampuan juga komitmen konselor agar dapat mengembangkan pendekatan konseling yang merefleksikan kebutuhan budaya konseli. (d) Kemampuan konselor agar dapat menghadapi peningkatan terhadap kompleksitas lintas budaya.

Macam-macam asumsi yang menjadi dasar pendekatan konseling transcultural daintaranya: (a) Kelompok budaya mempunyai kebenaran yang sama untuk kepentingan konseling; (b) Mayoritas budaya ialah musuh untuk seorang dari budaya

9 Muhammad, Fadhil. "Konseling Berbasis Wawasan Lintas Budaya Dalam Meningkatkan Sikap Toleransi Remaja." Jumal Suloh: Jumal Bimbingan Konseling FKIP Unsyiah 4(1) 2019. Hlm. 33.

${ }_{10}$ Mamat Supriatna. "Bimbingan dan Konseling Lintas Budaya." Materi PLPG PPB, FIP, UPI. 2019. Hlm. 4.

${ }^{11}$ Suryadi. "Cross Cultural and Cultural Counseling: Komunikasi Konseling Lintas Budaya Jawa Dan Madura Di Madrasah Aliyah Negeri 1 Jember." Konseling Edukasi : Journal of Guidance and Counseling 2(2) 2018. doi: 10.21043/konseling.v2i2.4468. Hlm. 99. 
yang lain. (c) Identitas seseorang saat berinteraksi dengan budaya akan berpengaruh terhadap outcome konseling.

Setiap agama pasti memberikan ajaran mengenai kedamaian juga rasa kemanusiaan. Meski berbeda keyakinan, agar tetapi bisa bekerjasana untuk hal yang diluar keagamaan sebab agama hanya menyangkut urusan pribadi dan tuhannya. Misalnya saat ada di situasi bencana, setiap korban memiliki hak agar mendapatkan bantuan tanpa memandang agama dan keyakinan. Cara pandang agama yang fanatik dapat memicu terjadinya konflik agama. Cara yang dapat dilakukan untuk mencegah hal itu terjadi adalah dengan memberikan pemahaman tentang keberagaman yang ada di sekitar melalui program konseling. ${ }^{12}$

\section{Radikalisme}

Kalimat radikalisme berawal dari bahasa latin "radix" yang memiliki arti akar, bagian bawah atau menyeluruh untuk menuntut perubahan. Kamus Besar Bahasa Indonesia (KBBI) menjabarkan bahwa radikalisme mempunyai penjelasan yaitu paham atau aliran yang radikal dalam politik, juga diartikan paham yang menginginkan perubahan ataupun pembaharuan sosial dan politik dengan cara yang anarkis, selain itu sering juga disebut sikap ekstrem dalam aliran politik. ${ }^{13}$

Radikalisme bisa dibedakan ke dalam dua level, yakni level pemikiran juga level tindakan. Pada level pemikiran, radikalisme ini berupa konsep yang masih didiskusikan, konsep ini berbau kekerasan agar dapat mencapai tujuan suatu kelompok. Sedangkan level tindakan, radikalisme ini sudah ada pada tahap melakukan aksi kekerasan untuk mencapai sebuah pembaharuan yang telah direncanakan oleh suatu kelompok. Level tindakan banyak terjadi pada ranah sosial, politik juga agama. Ranah politik dapat tercermin melalu tindakan aksi demonstrasi yang berujung pada kekerasan atau anarkis demi kepentingan politik untuk mencapai keuntungan dan mengakibatkan konflik yang panjang. ${ }^{14}$

Maka radikalisme dapat didefinisikan sebagai pemikiran dan sikap tidak toleransi antara satu sama lain, sikap menyalahkan pendapat orang lain dan sikap

12 Moh Ziyadul Haq Annajih, Kartika Lorantina, dan Hikmah Ilmiyana. "Konseling Multibudaya dalam Penanggulangan Radikalisme Remaja." 2017 Vol. 1. Hlm. 286.

13 Abdulloh Hadziq. "Nasionalisme Organisasi Mahasiswa Islam dalam Menangkal Radikalisme di Institut Agama Islam Negeri (IAIN) Surakarta | Jurnal Pendidikan Agama Islam AlThariqah." 2019. Diambil $25 \quad 2021$ (https://journal.uir.ac.id/index.php/althariqah/article/view/2791).

14 Zulfani Sesmiarni. "Membendung Radikalisme Dalam Dunia Pendidikan Melalui Pendekatan Brain Based Learning." Kalam 9(2): 2015. Hlm. 233-52. 
dengan cara kekerasan atau anarkis untuk mencapai sebuat kepentingan kelompoknya.

Dalam sisi keagamaan, fenomena radikalisme agama terlihat dari tindakantindakan anarkis yang mengatasnamakan agama. Tindakan tersebut dilakukan oleh sekelompok orang kepada kelompok agama lain atau sesama agama tetapi dianggpa penganut aliran yang dianggapnya sesat. Maka tindakan radikalisme agama ialah aktivitas yang memaksakan pendapat, keyakinan keinginan, dan cita-cita keagamaan melalui jalur kekerasan.

\section{Radikalisme di Sekolah}

Sikap radikalisme di sekolah dapat ditunjukan dengan rasa kurang menghargai kepada teman yang berbeda agama, suku maupun ras. Biasanya hal ini terjadi ketika ada kasus bullying yang dilakukan oleh sekelompok anak beragama mayoritas terhadap anak yang beragama minoritas. Aksi ini dapat ditunjukan dengan hanya mengolok-ngolok saja sampai dengan perilaku kekerasan dikarenakan tidak terima dengan perbedaan tersebut dan kurang adanya pengetahuan dan pemahaman tentang perbedaan yang dimiliki.

Lembaga Kajian Islam dan Perdamaian (LaKIP) Jakarta pada tahun 2010 meneliti tentang pendapat aksi radikalisme dan hasilnya sebanyak 48,9\% siswa di Jabodetabek memperikan pendapat bahwa setuju dengan aksi radikalisme. Hasil tersebut membuat guru menyadari bahwa kasus radikalisme dapat dilakukan oleh siswa-siswa. Persetujuan terhadap aksi radikal menimbulkan dampak negatif pada kepribadian dan sikap anak atau remaja seperti menganggap bahwa kekerasan boleh dilakukan demi mencapai suatu tujuan. Oleh karena itu anak-anak dan remaja memerlukan konseling dari seseorang yang ahli di bidangnya dan didampingi oleh guru supaya meminimalisir terjadinya sikap radikalisme di sekolah. ${ }^{15}$

\section{Faktor-Faktor Yang Menyebabkan Radikalisme}

Adapun beberapa factor yang menyebabkan terjadinya radikalisme antara lain; a) Pemahaman setengah-setengah dan tidak menyeluruh tentang agama, seperti pada ayat-ayat al-Qur'an. (b) Membaca sejarah yang salah karena sumber yang tidak valid sehingga kemungkinan yang dijadikan sumber tersebut tidak dapat di jamin keasliannya bahkan kemungkinan sudah dikombinasikan dengan idealisasi berlebihan terhadap Islam pada masa tertentu. (c) Kesenjangan politik, sosial dan ekonomi masih terjadi di masyarakat serta disorientasi dan dislokasi sosial-budaya.

${ }^{15}$ Noermala Sary. "Mencegah Penyebaran Paham Radikalisme Pada Sekolah.” Manthiq 2(2) 2017. doi: 10.29300/mtq.v2i2.673. Hlm. 193. 
(d) Kelompok radikalisme memanfaatkan internet, media kertas, dunia maya untuk menyebarkan informasi mengenai suatu masalah yang dapat berujung pada radikalisme. (e) Remaja dijadikan sasaran utama penyebaran paham radikalisme karena tingginya rasa ingin tahu pada remaja. Kondisi seperti ini dimanfaatkan untuk membawa remaja untuk masuk kedalam diskusi kelompok radikal yang kemudian berujung pada aksi radikal yang dapat merugikan banyak orang.

\section{Bentuk Penanggulangan Radikalisme Pada Anak-anak}

Pendidikan konseling lintas budaya sangat dibutuhkan dan penting untuk dilakukan terhadap anak-anak. Hal tersebut dikarenakan dapat menanamkan rasa dan sikap toleransi sejak dini maka dapat dipastikan generasi penerus bangsa dimasa yang akan datang dapat menjadi lebih baik lagi, memahami dan menghormati perbedaan satu dengan yang lainnya. Pernyataan diatas menunjukan bahwa masa anak-anak adalah masa emas untuk menentukan dan membentuk pribadi dimasa yang akan datang. Masa anak-anak memerlukan kegiatan-kegiatan positif yang bertujuan untuk menanamkan sikap saling menghargai dan menghormati antara satu sama lain. Kegiatan tersebut harus dikemas semenarik mungkin tanpa menghilangkan prinsip dunia bermain pada anak. ${ }^{16}$

Kegiatan konseling dibuat menarik dan tidak menghilangkan unsur bermain bersama. Tujuan dari kegiatan ini adalah membentuk interaksi antara anak satu dengan anak yang lainnya kemudian mengenalkan konsep dasar keberagaman yang ada sehingga timbul suasana dan rasa persahabatan dan tidak membeda-bedakan antara satu sama lain. Kegiatan ini akan sangat bermanfaat untuk menciptakan persahabatan dan persaudaraan, dan sebagai wadah untuk anak tumbuh, kembang dan berekspresi. ${ }^{17}$

\section{Bentuk Penanggulangan Paham Radikalisme Pada Remaja}

Remaja merupakan masa peralihan dari kanak-kanak menuju masa dewasa dimana banyak terjadi perubahan dari segi fisik maupun psikis remaja. Psikis yang labil akan mengakibatkan remaja cenderung tidak bisa untuk memanajemen emosinya sehingga remaja perlu perhatian lebih dari orang tuanya untuk dapat menjaga dan mengawasi hal-hal yang dilakukan oleh remaja. Pengawasan perlu

16 Nurhastuti. "Evaluasi Pemahaman Orang Tua tentang Anak Attetion Defisit Hiperaktif Disorder (ADHD) dengan Metode Konseling Lintas Budaya." 2011.

17 Rifda El Fiah dan Ice Anggralisa. "Efekitvitas Layanan Konseling Kelompok Dengan Pendekatan Realita Untuk Mengatasi Kesulitankomunikasi Interpersonal Peserta Didik Kelas X MAN Krui Lampung Barat T.P 2015/2016.” KONSELI : Jurnal Bimbingan Dan Konseling (EJournal) 2(2) 2015.43-56. doi: 10.24042/kons.v2i2.1207. 
dilakukan agar remaja tidak terjerumus kedalam hal-hal negatif. Fase remaja ini seseorang mencari jati dirinya dan hal ini dipengaruhi oleh lingkungan sekitarnya. ${ }^{18}$

Menurut World Health Organization (WHO) remaja adalah suatu masa ketika pertama kali individu menunjukkan tanda-tanda seksual sekundernya sampai mencapai kematangan seksual, individu juga mengalami perkembangan psikologi tercermin dari pemikiran dan tingkah laku yang sudah tidak anak-anak lagi dan mencapai titik kemandirian dari segi sosial dan ekonomi. ${ }^{19}$

Empat ciri-ciri utama yang harus diperhatikan dalam perkembangan remaja, yaitu aktifnya organ-organ reproduksi yang ditunjukan oleh bentuk tubuh yang berbeda, lebih tertarik pada teman sebayanya, timbul rasa ingin kebebasan dan mandiri dan keinginan remaja untuk menentukan tujuan hidupnya di masa depan dan pola tertentu yang akan dijadikan pedoman bertingkah laku sebagai manusia dewasa. Hal ini berkaitan dengan kemunculan aksi radikalisme yang dilakukan oleh kalangan remaja. Perkembangan fisik dan psikis pada remaja ialah masa yang cukup berpengaruh terhadap lingkungan disekelilingnya. Salah satu tugas perkembangan remaja itu harus bertanggung jawab sebagai warga negara, bertanggung jawab atas tingkah lakunya dan berkembang atas nilai-nilai yang ada di masyarakat. ${ }^{20}$ Apabila tugas perkembangan remaja dapat dijalankan dengan baik maka remaja akan mampu mengendalikan dirinya untuk bertindak sesuai dengan aturan yang berlaku. Adapun tugas perkembangan remaja tidak berhasil dijalankan, maka yang akan terjadi yakni remaja menjadi individu yang kurang peka dan cenderung akan melanggar aturan dan norma yang berlaku.

\section{Upaya Konseling Dalam Penggulangan Radikalisme}

Anak-anak dan remaja dituntut untuk selalu berkembang dan mencapai suatu standar sosialnya. Standar sosial dapat berupa tuntutan standar dari orang tua dan keluarga atau tuntutan dari lingkungan sekolah maupun lingkungan masyarakat. Hal ini mengakibatkan pandang tentang pendidikan harus sama atau harus sesuai dengan

18 Nindya Putri Novita. "Hubungan antara kekerasan emosional pada anak terhadap kecenderungan kenakalan remaja." 2012.

19 Nuriyanto, Lilam Kadarin. 2014. "Bimbingan Konseling Melalui Pendidikan Multikultural terhadap Anak-Anak dan Remaja dalam Penanggulangan Paham Radikalisme.” Konseling Religi: Jurnal Bimbingan Konseling Islam 5(1): 2014. Hlm. 28.

${ }^{20}$ J. Franz Monks dan Alphonsus Maria Petrus Knoers. "Psikologi Perkembangan; Pengantar dalam berbagai bagiannya." 2014. 
standar. Teori belajar behavioristik berfokus pada aspek input yaitu stimulus dan aspek output yaitu respon. ${ }^{21}$

Belajar adalah proses interaksi antara dorongan dan respon tingkah laku dari seseorang. Teori belajar sosiokultur mendukung adanya konsep multibudaya. Maka dari itu perubahan mental remaja dipengaruhi oleh proses sosial yang dialaminya. ${ }^{22}$ Teori tersebut sangat relevan dengan kenyataan yang terjadi bahwa perkembangan siswa sangat dipengaruhi oleh faktor lingkungan maka setiap anak memiliki perbedaan dalam berkembang. ${ }^{23}$

Teori Vygotsy sangat sesuai dengan kondisi bangsa Indonesia yang beragam, mengakui adanya perbedaan, dan dapat menerima perbedaan ras, suku maupun agama. ${ }^{24}$ Bimbingan dan konseling memiliki peran yang efektif dalam menanamkan nilai-nilai keberagaman budaya di lingkungan sekolah. Layanan konseling ini bertujuan agar siswa-siswi dapat menerima adanya perbedaan dan menghormati perbedaan yang muncul di lingkungan sekitarya. ${ }^{25}$ Dukungan sekolah dalam tahap konseling ini memiliki dampak yang sangat positif bagi pembentukan kepribadian yang baik bagi siswa-siswinya.

Pola keberagaman budaya dalam praktik konseling merupakan komponen penting karena dapat menentukan pembentukan kepribadian siswa-siswi agar memahami adanya perbedaan dan menghormati perbedaan tersebut. Pernyataan tersebut dapat menunjukkan bahwa kegiatan konseling dapat berjalan dengan efektif apabila konselor yang dipilih sesuai dan ahli di bidangnya. Kegiatan konseling ini akan membantu siswa-siswi untuk memiliki keterampilan beradaptasi yang baik di lingkungannya. ${ }^{26}$

Konsep konseling dilakukan oleh konselor untuk menanggulangi proses penyebaran paham radikalisme adalah dengan koseling lintas budaya. Konsep ini menitik beratkan pada penanaman pemahaman bahwa Indonesia merupakan negara dengan keberagaman yang mewajibkan selurus warga negaranya untuk menghargai

${ }^{21}$ Novi Irwan Nahar. "Penerapan teori belajar behavioristik dalam proses pembelajaran." Nusantara: jurnal ilmu pengetahuan sosial 1(1) 2016. Hlm. 66.

22 Sisca Rahmadonna. Teori Belajar Sosiokultur (Lev Vygotsky). 2010.

${ }^{23}$ Lev Semenovich Vygotsky dan Michael Cole. Mind in society: Development of higher psychological processes. (Harvard university press. 1978)

24 Ibid., 1978.

${ }^{25}$ Siti Imro'atun. "Keefektifan layanan konseling kelompok untuk meningkatkan kepercayaan diri siswa sekolah menengah pertama." Jurnal Kajian Bimbingan dan Konseling 2(2) 2017. Hlm. 54.

${ }^{26}$ Itsar Bolo Rangka. "Konseling Indigenous: Rekonstruksi Konseling di Tengah Keragaman Budaya." Optimalisasi Peran Konselor Melalui Pemanfaatan Berbagai Pendekatan Dan Terapi Dalam Pelayanan Konseling. 2016. Hlm. 4. 
satu sama lain. Pendekatan konseling lintas budaya sangat diperlukan agar remaja mengetahui dan memahami arti keberagaman yang ada dan mampu menerima bahwa perbedaan tidak akan membawa dampak negatif justru perbedaan akan membuat semakin indah dengan hidup rukun dan berdampingan. ${ }^{27}$ Apabila remaja sudah diberikan pemahaman mengenai keberagaman maka di masa depan remaja akan menjadi generasi penerus bangsa yang memiliki jiwa dan sikap toleransi yang tinggi dan mudah beradaptasi dengan keberagaman yang ada di sekitarnya.

Remaja masih memiliki sifat yang labil dan kurang handal dalam mengelola emosinya. Selain itu, remaja juga memiliki keinginan untuk mencapai tujuan hidup dan memerlukan dasar yang dijadikan pedoman untuk bertingkah laku sebagi orang dewasa. Sebagai dasar atau pondasi pembentukan sikap, maka perlu diadakan kegiatan-kegiatan yang di dalamnya menanamkan nilai-nilai keberagaman budaya.

Konsep bimbingan dan konseling lintas budaya dan agama dalam menanggulangi radikalisme di kalangan remaja menggunakan konsep psikologi perkembangan remaja. Pendekatan konseling lintas budaya dan agama sebagai tempat untuk mendapatkan edukasi mengenai keberagaman sehingga peserta konseling dapat lebih saling menghormati dan menerima satu dengan yang lain. Kaum mayoritas bisa menghormati terhadap kaum minoritas. Sebaliknya, kaum minoritas bisa menghormati keberadaan kaum mayoritas. Konsep untuk saling menghargai dan menerima satu dengan yang lain merupakan modal dalam membina kerukunan pada kelompok masyarakat yang plural. ${ }^{28}$

1. Layanan Konseling Multibudaya

McCoy memaparkan bahwa konselor memerlukan kesadaran, pengetahuan dan keterampilan untuk mengembangkan diri sebagai konselor dalam konseling lintas budaya. Keasadaran yang dimaksud adalah kesadaran adanya perbedaan kultural antara konselor dan peserta konseling. Kesadaran tesebut sangat dibutuhkan karena merupakan faktor utama untuk menentukan arah dari konseling dan dapat menimbulkan presepsi peserta konseling. ${ }^{29}$

Pengetahuan yang dimaksud adalah konselor harus memiliki pengetahuan tentang konsep bimbingan atau konseling lintas budaya.

27 Ahmad Susanto. Bimbingan dan konseling di Sekolab: Konsep, teori, dan aplikasinya. (Kencana. 2018). Hlm. 190.

28 Annajih, Moh Ziyadul Haq, Kartika Lorantina, dan Hikmah Ilmiyana. 2017. "Konseling Multibudaya dalam Penanggulangan Radikalisme Remaja.” 2017. dalam Vol. 1. Hlm. 287.

${ }^{29}$ Cheryl Holcomb-McCoy, Paul Harris, Erik M. Hines, dan Georgina Johnston. "School counselors' multicultural self-efficacy: A preliminary investigation." Professional School Counseling, 2008. 11(3):2156759X0801100303. Hlm. 168. 
Pengetahuan yang harus dimiliki konselor antara lain kebudayaan, ras, etnik, etik dan emik, agama, kelompok minoritas dan mayoritas..$^{30}$ Wawasan tersebut dapat didapat dengan kajian sumber yang valid, penelitian yang berhubungan dengan hal tersebut dan pengalaman pada saat melakukan konseling dengan peserta konseling.

Keterampilan yang dimaksudkan adalah ketrampilan yang bermanfaat bagi kegiatan konseling. Konselor diharapkan mampu menerapkan strategi dan metode yang tepat sesuai dengan peserta konseling sehingga konseling dapat berjalan dengan lancar dan efektif. Kesadaran dan pengetahuan adalah faktor yang dapat menentukan keterampilan konselor. ${ }^{31}$

Kegiatan konseling ini diharapkan dapat menyadarkan siswa-siswi terhadap keberagaman yang ada disekitar dan menumbuhkan sikap toleransi antara satu sama lain. Hal tersebut dapat menghindarkan suatu kesalahan presepsi tentang keberagaman dan dapat mencegah terjadinya radikalisme dikalangan pelajar.

2. Layanan Bimbingan konseling keagamaan

Layanan bimbingan konseling keagamaan merupakan cara yang efektif untuk menangani radikalisme dan program ini akan dilakukan oleh orang yang ahli dan profesional sesuai bidangnya. Peserta di kegiatan ini adalah remaja karena remaja memiliki sikap yang labil sehingga dengan mudah dapat dijadikan sasaran utama permasalahan radikalisme. ${ }^{32}$ Program ini dilakukan dengan cara konselor memberikan pemahaman mendalam mengeani kepercayaan, budaya dan keyakinan masing-masing individu, memberikan saran untuk mendekatkan diri kepada tuhan dan peserta konseling diberikan pengetahuan dan pemahaman mengani sikap toleransi. Belajar agama yang benar, menyeluruh dan tidak setengah-setengah akan menguatkan aqidah seseorang sehingga terhindar dari radikalisme agama. ${ }^{33}$ Tujuan dari kegiatan ini adalah menumbuhkan rasa dan sikap toleransi antar suku, ras dan agama.

\section{KESIMPULAN}

30 Ahmad Susanto. Bimbingan dan konseling di Sekolab: Konsep, teori, dan aplikasinya. (Kencana. 2018). Hlm. 123.

31 Rezki Hariko. "Landasan filosofis keterampilan komunikasi konseling." Jurnal Kajian Bimbingan dan Konseling, 2017 2(2) Hlm. 45.

32 Deni, Febrini. Bimbingan konseling. (Yogyakarta: Teras. 2011).

33 Rezki Hariko, "Landasan filosofis keterampilan komunikasi konseling." Jurnal Kajian Bimbingan dan Konseling 2(2): 2017. Hlm. 47. 
Semua agama dasarnya ingin damai. Islam merupakan agama yang damai dan memiliki toleransi yang tinggi. Radikalisme di Indonesia muncul pada masa akhir orde baru. Hal tersebut ditandai dengan munculnya berbagai aliran-aliran yang ingin menunjukan pemahaman dan menerapkan sesuatu yang keyakinan dan dipercaya kelompoknya. Radikalisme timbul dan berkembang diakibatkan oleh faktor internal dan faktor eksternal. Faktor internal yang dimaksud adalah permahaman yang salah terhadap sejarah yang dipercayai dan faktor eksternal yang dimaksud adalah ketidaksukaan terhadap suatu kelompok atau penguasa.

Terjadinya kondisi tersebut dapat dikendalikan melalui kegiatan konseling. Remaja menjadi sasaran utama kegiatan konseling agar tidak terjerumus pada tingkah laku radikalisme. Konseling yang tepat dan efektif untuk permasalahan ini adalah konseling multi budaya dan agama. Kegiatan tersebut membutuhkan konselor yang tepat dan ahli dibidangnya. Oleh karena itu konselor membutuhkan pelatihan yang kompeten untuk memperluas wawasan dan keterampilan konselor. Dengan adanya kondisi tersebut maka konselor dalam konseling multibudaya memerlukan awareness, knowledge, dan skills dalam konsep multibudaya. Setelah kegiatan konseling berjalan dengan lancar diharapkan peserta konseling dapat dengan mudah beradaptasi dengan berbagai keberagaman yang ada di sekitarnya 


\section{DAFTAR PUSTAKA}

Ahmad Susanto, M. Pd. 2018. Bimbingan dan konseling di Sekolah: Konsep, teori, dan aplikasinya. Kencana.

Anas, Aijudin. 2011. "Peran Pesantren Al Muayyad Windan Dalam Transformasi Konflik Keagamaan Di Surakarta."

Annajih, Moh Ziyadul Haq, Kartika Lorantina, dan Hikmah Ilmiyana. 2017. "Konseling Multibudaya dalam Penanggulangan Radikalisme Remaja." Hlm. 280-91 dalam Vol. 1.

Bukhori, Baidi. 2014. "Dakwah Melalui Bimbingan dan Konseling Islam.” Jurnal Konseling Religi 5(1):1-18.

Deni, Febrini. 2011. "Bimbingan konseling." Yogyakarta: Teras.

Fiah, Rifda El, dan Ice Anggralisa. 2015. "Efekitvitas Layanan Konseling Kelompok Dengan Pendekatan Realita Untuk Mengatasi Kesulitankomunikasi Interpersonal Peserta Didik Kelas X MAN Krui Lampung Barat T.P 2015/2016." Konseli : Jurnal Bimbingan Dan Konseling (E-Journal) 2(2):4356. doi: 10.24042/kons.v2i2.1207.

Hadziq, Abdulloh. 2019. "Nasionalisme Organisasi Mahasiswa Islam dalam Menangkal Radikalisme di Institut Agama Islam Negeri (IAIN) Surakarta | Jurnal Pendidikan Agama Islam Al-Thariqah." Diambil 25 November 2021 (https://journal.uir.ac.id/index.php/althariqah/article/view/2791).

Hariko, Rezki. 2017. "Landasan filosofis keterampilan komunikasi konseling." Jurnal Kajian Bimbingan dan Konseling 2(2):41-49.

Hartono, M. Si. 2015. Psikologi Konseling. Kencana.

Holcomb-McCoy, Cheryl, Paul Harris, Erik M. Hines, dan Georgina Johnston. 2008. "School counselors' multicultural self-efficacy: A preliminary investigation." Professional School Counseling 11(3):2156759X0801100303.

Imro'atun, Siti. 2017. "Keefektifan layanan konseling kelompok untuk meningkatkan kepercayaan diri siswa sekolah menengah pertama." Jurnal Kajian Bimbingan dan Konseling 2(2):50-57.

Monks, J. Franz, dan Alphonsus Maria Petrus Knoers. 2014. "Psikologi Perkembangan; Pengantar dalam berbagai bagiannya."

Muhammad, Fadhil. 2019. "Konseling Berbasis Wawasan Lintas Budaya Dalam Meningkatkan Sikap Toleransi Remaja." Jurnal Suloh: Jurnal Bimbingan Konseling FKIP Unsyiah 4(1).

Munip, Abdul. 2012. "Menangkal radikalisme agama di sekolah.” Jurnal Pendidikan Islam 1(2):159-81.

Nahar, Novi Irwan. 2016. "Penerapan teori belajar behavioristik dalam proses pembelajaran.” NUSANTARA: jurnal ilmu pengetahuan sosial 1(1).

Novita, Nindya Putri. 2012. "Hubungan antara kekerasan emosional pada anak terhadap kecenderungan kenakalan remaja."

Nurhastuti, Nurhastuti. 2011. "Evaluasi Pemahaman Orang Tua tentang Anak Attetion Defisit Hiperaktif Disorder (ADHD) dengan Metode Konseling Lintas Budaya."

Nuriyanto, Lilam Kadarin. 2014. "Bimbingan Konseling Melalui Pendidikan 
Multikultural terhadap Anak-Anak dan Remaja dalam Penanggulangan Paham

Radikalisme.” Konseling Religi: Jurnal Bimbingan Konseling Islam 5(1):19_40.

Rahmadonna, Sisca. 2010. "Teori Belajar Sosiokultur (Lev Vygotsky)."

Rangka, Itsar Bolo. 2016. "Konseling Indigenous: Rekonstruksi Konseling di

Tengah Keragaman Budaya." Optimalisasi Peran Konselor Melalui

Pemanfaatan Berbagai Pendekatan Dan Terapi Dalam Pelayanan Konseling 19-20.

Sari, Milya, dan Asmendri Asmendri. 2020. "Penelitian Kepustakaan (Library Research) dalam Penelitian Pendidikan IPA.” Natural Science: Jurnal Penelitian Bidang IPA dan Pendidikan IPA 6(1):41-53. doi: 10.15548/nsc.v6i1.1555.

Sary, Noermala. 2017. "Mencegah Penyebaran Paham Radikalisme Pada Sekolah." Manthiq 2(2):191-200. doi: 10.29300/mtq.v2i2.673.

Sesmiarni, Zulfani. 2015. "Membendung Radikalisme Dalam Dunia Pendidikan Melalui Pendekatan Brain Based Learning." Kalam 9(2):233-52.

Supriatna, Mamat. 2009. "Bimbingan dan Konseling Lintas Budaya.” Materi PLPG PPB, FIP, UPI.

Suryadi, Suryadi. 2018. "Cross Cultural and Cultural Counseling: Komunikasi Konseling Lintas Budaya Jawa Dan Madura Di Madrasah Aliyah Negeri 1 Jember." Konseling Edukasi: Journal of Guidance and Counseling 2(2). doi: 10.21043/konseling.v2i2.4468.

Suwito, Anton. 2014. "Membangun Integritas Bangsa Di Kalangan Pemuda Untuk Menangkal Radikalisme.” CIVIS 4(2). doi: 10.26877/civis.v4i2/Juli.610.

Tisa, Mutia. 2017. "Prasangka Sosial Dalam Perspektif Komunikasi Antar Budaya Dan Agama." At-Tanzir: Jurnal Ilmiah Prodi Komunikasi Penyiaran Islam 7586.

Vygotsky, Lev Semenovich, dan Michael Cole. 1978. Mind in society: Development of higher psychological processes. Harvard university press.

Wadi, Ardi Andika. 2019. "Bimbingan Konseling Lintas Agama dan Budaya dalam Penanggulangan Radikalisme bagi Remaja.” Jurnal Al-Irsyad: Jurnal Bimbingan Konseling Islam 1(2):174-86. 